\title{
The Circular Economy in Affordable Housing to Reach Carbon Neutrality - Refurbishment
}

\author{
Silja TILLNER, Architects Tillner \& Willinger, Austria, Polimi, Italy \\ Marco PEVERINI, Dipartimento di Architettura e Studi Urbani (Dastu), Politecnico di Milano, Italy
}

\begin{abstract}
With new construction and land consumption becoming more and more inappropriate, refurbishment of the existing building stock provides a chance to achieve the ambitious 1.5-degree goals while improving the living situation in densely populated residential districts and providing (or maintaining) affordable housing. Refurbishment is however challenging the traditional modes of housing production and transformation and, with the scarcity of building materials, we need innovative ways to carry out it. The paper, after introducing the themes and problems, describes some interesting examples of renovation of affordable housing and the Viennese policy for "gentle urban renewal" and discusses opportunities and challenges in these different models. Then, it introduces the principles of circular economy and discusses how today affordable design solutions can be combined with environmental goals in new construction and renovation while achieving $\mathrm{CO}_{2}$ neutrality. The application of cradle-to-cradle principles and reuse of materials in the refurbishment and adaptation of existing affordable housing represent a challenging and promising perspective for research, design and policy.
\end{abstract}

Keywords

Climate Crisis, Resilience, Affordable Housing, Circular Economy, Refurbishment

\section{Introduction}

The dynamics taking place in the big cities of Europe and the world pose a series of challenges and unprecedented demands. On the one hand, the need for affordable housing has increased due to the growing population in cities like Milan and Vienna, which are the contexts of this study. On the other hand, phenomena related to climate change are affecting the livability of human settlements and require mitigation and environmental solutions that should be combined with the necessary refurbishment of the existing housing stock. Most large cities worldwide have recently experienced the dramatic effects of the climate crisis.

To meet the 1.5-degree pathway and the Paris goals, cities must reduce $55-60 \%$ of their net emissions by 2030. The cities of Vienna and Milan have been impacted by Urban Heat Islands (UHI) phenomena, which are particularly critical in densely populated residential districts. Climate change challenges housing in several ways: New construction, as well as the operation of existing buildings significantly contribute to $\mathrm{CO}_{2}$ emissions. As one of the major causes of carbon emissions, buildings therefore constitute a crucial field of action for mitigation and future reduction. 
Modern tools of urban development and housing production after World War II have proven unable to face both challenges, leaving a huge stock of environmentally unsustainable post-war housing in vulnerable urban fabrics. However, even more contemporary standards applied to retrofitting have not sufficiently increased its environmental qualities. Since housing is an inertial object, new construction and transformation is hardly reversible and the consequences of today's errors can last for decades. We urgently need innovation in the way we produce and (especially) transform the housing stock to provide more spaces for livability and sustainability. As made explicit by the recent crisis in the provision of building materials, the circular economy (CE) is, in this sense, a very useful concept to innovate housing production and transformation in a more sustainable way.

The principles of reusing, recycling and recirculating materials can no longer be relegated to certain demonstration projects, but should be applied in every single project if the 1.5-degree goal is to be reached. This will be a daunting task for affordable housing production, which is already under economic pressure due to increased land and construction costs. Moreover, the scarcity of resources and building materials resulting from the Covid-19 crisis have further raised the costs.

In this context, design and regulation can play key roles. By following the cradle-to-cradle principles of a circular economy, this contribution offers a potential solution. Architectural design based on a circular economy can combine affordable design solutions with environmental goals and integrate green concepts in new construction and renovation while achieving $\mathrm{CO}_{2}$ neutrality. Targeting the refurbishment of the existing building stock provides a huge chance to achieve the ambitious 1.5-degree goals while improving the living situation of city dwellers. In addition, building regulations often hinder both ecological refurbishment and architectural innovation. If redrafted according to circular economy principles, they could stimulate sustainable housing developments and the integration of green measures. Starting from these environmental, social and economic challenges and focusing on the cities of Vienna and Milan and on the countries of Austria and Italy, the research will investigate opportunities for refurbishment innovation to improve green and environmental standards in housing production and renovation through CE and, ultimately, to enable better, still affordable and more livable housing experiences. Some interesting examples will be discussed.

\section{Problem Definition}

\subsection{Trends in the Housing Supply}

The construction sector is considered to play a key role in the economy of both Austria (around 6\% of GDP) and Italy (around $4 \%$ of GDP), as well as in many other countries. Housing production and housing prices trends are seen as indicators of positive or negative economic performance, but how do they affect the challenges of climate change, adaptation and mitigation?

Buildings are responsible for $40 \%$ of the EU-wide energy consumption. In Austria, the building sector accounts for $35 \%$ of the energy consumption and housing constitutes $70 \%$ of the $35 \%$, i.e., a quarter of the entire Austrian energy usage ${ }^{1}$. The problems in the building sector, especially in housing, result from several factors.

A first issue regards new construction. Until now, both the Italian and Austrian construction sectors have relied heavily on new housing production, also an indicator of economic performance (77,699 new dwellings in Austria in 2019, 54,935 in Italy in 2018), despite the fact that the number of housing units is 
equal or above the number of households. In Italy there are around 30 million dwellings (Agenzia delle Entrate, 2019) for around 25.7 million households (Istat, 2020); in Austria there were 4.4 million dwellings counted in the 2011 census for around 4 million households (Statistik Austria, 2019). New construction activity generally entails the consumption of soil (soil sealing), a precious and non-renewable resource, which is high in both Italy (additional $57 \mathrm{~km}^{2}$ sealed in 2020) and Austria (additional $39 \mathrm{~km}^{2}$ sealed in 2020). This is a worrying trend that should be stopped as soon as possible. The focus should be shifted towards refurbishment or substitution and, when possible, soil desealing.

A second issue connected to the theme of refurbishment regards the age of the building stock. In both Austria and Italy the biggest part has reached over fifty years (Fig. 1). In Austria, according to Statistik Austria approximately one building in seven was erected before 1919; only about one in 13 from the years 1919 to 1944; 28.8\% (the largest proportion) during the years 1971 to 1990; one fourth after 1990. In Vienna, the inventory of older buildings (erected before 1945) differs significantly from that of the other federal provinces. One fifth of the buildings was built before 1919; another 15.2\% in the interwar period and during World War II, respectively. In Italy, according to Istat, 15.0\% were built before 1919; around 10\% between 1919 and 1946; over one fourth between 1946 and 1990; approximately 15\% afterwards. Although often very energy-intensive, those buildings contain a large amount of "embedded energy" in terms of materials and energy embedded in its construction that should be taken into account.

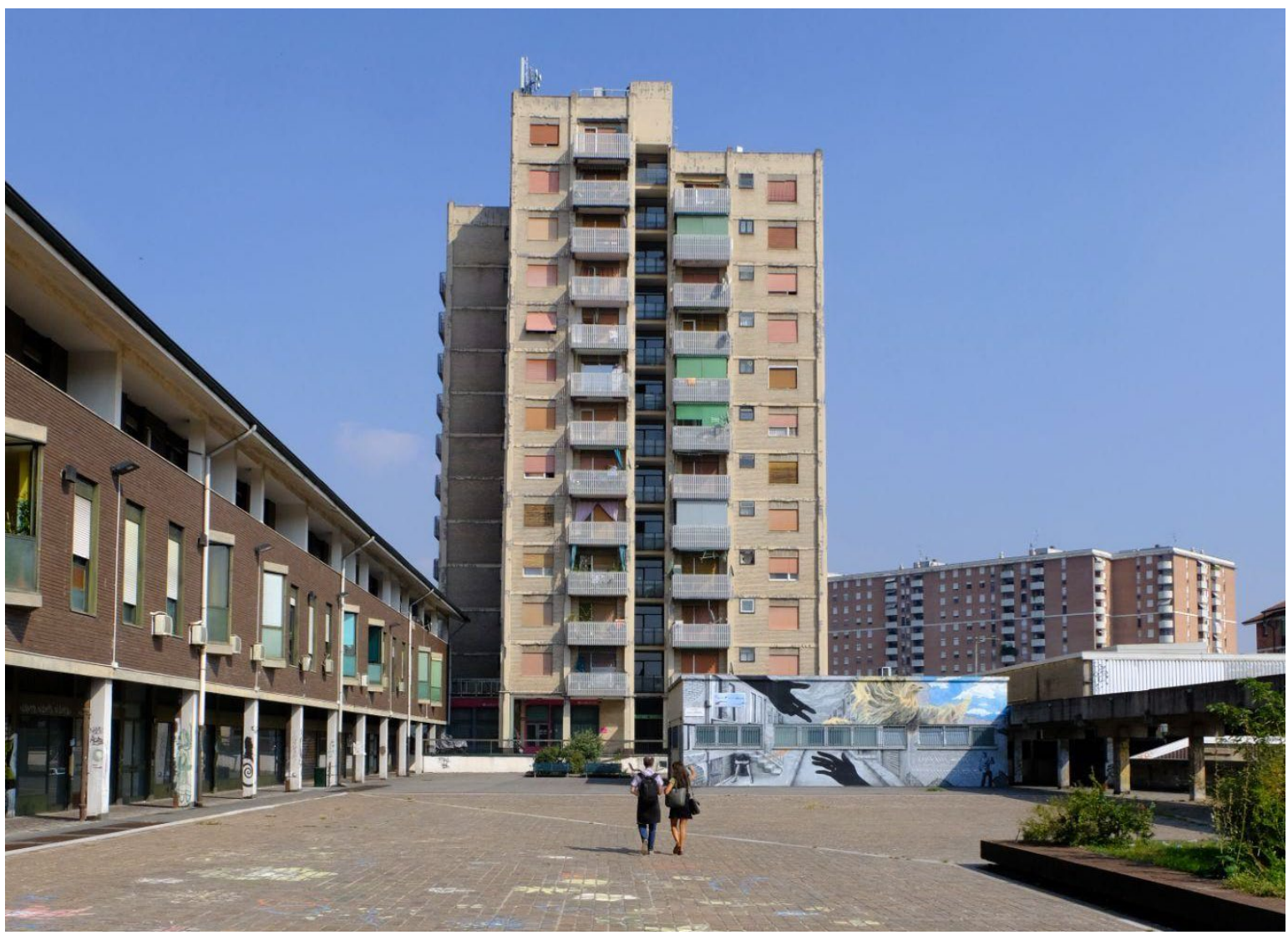

Figure 1. The Chiesa Rossa neighborhood in Milan. Source: Marco Peverini

A third issue is the increase in comfort requirements. In Austria, the net floor space per capita has risen continuously to $45 \mathrm{~m}^{2} /$ person in 2020 and is expected to rise to $55 \mathrm{~m}^{2} /$ person until 2050. Coherently, warm water usage has risen continuously and, also due to increased urban heat islands, electricity demand for ventilation and cooling is increasing. Currently, the increase in comfort requirements corresponds to the 
improvements in the energy-efficiency of building services and domestic engineering. These three themes highlight the need to not only stop new constructions, but to rethink our living and comfort standard and to shift the emphasis towards forms of refurbishment that maintain as much "embedded energy" as possible.

\subsection{Policies and Targets (EU, Austria, Italy)}

\subsubsection{EU Goals and Strategies, 2021}

The European Green Deal was first presented in December 2019 when Ursula von der Leyen took office. It targets no net emissions of greenhouse gases by 2050 and at least a $55 \%$ reduction by 2030 compared to 1990 levels. Economic growth shall be uncoupled from the use of resources. The European Green Deal is also the lifeline out of the COVID-19 pandemic. One third of the 1.8 trillion euros in investments from the NextGenerationEU Recovery Plan, and the EU's seven-year budget will finance the EU Green Deal'2.

When focusing on construction and renovation, the building sector in general and affordable housing in particular, it becomes clear that a large positive impact can be generated by a renovation wave following the principles of circular economy. In the chapter "Leading the third industrial revolution," the official website of the EU mentions that 35 million buildings could be renovated by 2030 and 160,000 new green jobs could be created in the construction sector by $2030^{3}$. When looking at the Green Deal in detail, there are new laws, regulations and guidelines which will have to be transformed into legally binding national laws and regulatory frameworks to lower emissions. This will permanently change the way we design, construct and use our buildings. Member State greenhouse gas emission reductions pursuant to article 4(1) detail the necessary reductions in 2030 in relation to their 2005 levels by state, depending on their gross domestic product (GDP /capita), Germany 38\% (= $485 \mathrm{M}$ tons to 83 million inhabitants), Austria $36 \%$ (= 57 $M$ tons to 8.9 million inhabitants), Italy $33 \%$. Poorer countries have to reduce less, e.g., Croatia $7 \%$, (= 18 $\mathrm{M}$ tons to 4.1 million inhabitants), Bulgaria $0 \%$ (= $81 \mathrm{M}$ tons to 7 million inhabitants). By the end of 2021, the European Performance of Buildings Directive (EPBD) will be revised towards energy- and resourceefficient building and renovation and initiate a renovation wave. In 2021, one lighthouse initiative to jumpstart this wave is the New European Bauhaus (NEB) initiative. When introducing this initiative, Ursula von der Leyen stated, "I want NextGenerationEU to kickstart a European renovation wave and make the Union a leader in the circular economy." The innovative aspect of this interdisciplinary initiative lies in its equally high environmental and economic ambitions while equally aspiring to become a new cultural project for Europe. The reference to the renowned Bauhaus from the beginning of the 20th century demonstrates the importance of quality in design combined with innovation in technology, building materials and technique ${ }^{4}$.

\subsubsection{Towards Solutions in the Building Sector}

The goal is to reduce emissions by approx. $90 \%$ until 2050. The aim of the Energy Performance of Buildings Directive (EPBD) 2010/31/EU is to improve the energy performance of buildings in the EU taking into account various climatic and local conditions ${ }^{5}$. It was revised in 2020 to include the strategy for a renovation wave and apply stricter energy performance standards for buildings. New are requirements on sustainable mobility, resource efficiency instead of energy efficiency, the consideration of circular economy principles, life-cycle costs, digitalization, climate resilience (e.g., green infrastructure), health and ecology. To prove the climate resilience of buildings, risks have to be analyzed using future climate and weather data. Water usage has to conform to the EU water-label. A minimum of $80 \%$ of used building materials has to be ecological and suitable for circular usage, i.e., cradle-to-cradle certified. No pollutants are allowed, 
neither in the materials nor during construction. Wood has to be either certified as being from sustainable forestry or re-used.

The following actions have to be taken in order to reach this goal:

- $\quad$ Building emissions shall be included in the European emission trade.

- Transformation to efficient alternative energy systems

- Doubling of renovation rate by 2030 by:

$\circ \quad$ Increase in subsidies

- Elimination of regulatory hurdles

- Increased funding for affordable housing

- Development of long-term renovation strategies by the Member States until 2020. In Austria this is the OIB Building Guideline ${ }^{6}$.

A renovation wave for Europe - the priorities are ${ }^{7}$ :

- Tackling energy poverty and worst-performing buildings

- $\quad$ Renovation of public buildings

- Decarbonization of heating and cooling

- Application of the $10 \mathrm{Rs}$ of $\mathrm{CE}$, i.e., the principles of circular economy, to each renovation project

- Respect for architectural heritage, development of sensitive solutions for energy-efficiency using the newest technologies

\subsubsection{The Role of Financing}

Financing systems are a powerful instrument to steer investments towards ecological projects and prevent unsustainable ones. The EU taxonomy is a classification system, establishing a list of environmentally sustainable economic activities ${ }^{8}$. It will change the financing conditions by January 1,2022 . The six main environmental objectives of the EU taxonomy are:

- $\quad$ Climate change mitigation

- Climate change adaptation

- $\quad$ Sustainable use and protection of water and marine resources

- Transition to a circular economy

- Pollution prevention and control

- $\quad$ Protection and restitution of healthy ecosystems and biodiversity

Concluding, the EU Green Deal plans to achieve greenhouse gas neutrality by 2050 with the methodology of $\mathrm{CO}_{2}$ pricing, circular economy, mobility- and energy transition, and the redirection of financial flows. Controls, evaluation and motivation will depend on regular reports by the Member States and funding and subsidies of green investments. The Green Deal will be at the center of EU recovery and mark a New Deal.

\subsection{Connecting Environmental and Affordability Issues}

Most cities in the world, including Milan and Vienna, are facing a housing affordability crisis driven mostly by an increase in housing prices (Wetzstein, 2017). The causes of the rise in housing prices are connected with various phenomena, among which the commodification of housing and (especially) of land are predominant. In the last three decades, the growth in housing prices has predominantly depended on the appreciation of the underlying land assets, ranging from $40 \%$ to over $77 \%$ of the total depending on countries, as shown by a recent study conducted in 14 advanced countries (Knoll, Schularick, and Steger, 
2017). More recently, however, there have been signs of an increasing weight on the non-land components, especially the cost of building materials, due to the crisis in provision and supply chains. In this sense, both aspects should be targeted in order to increase affordability. However, as we saw, land and building materials are two crucial aspects in determining the overall sustainability of housing production and transformation processes.

\subsubsection{Land Price and Interest Rates as a Cost Driver}

For the aforementioned reasons, land consumption should be avoided. This is, however, a very challenging target in growing cities like Vienna and Milan, where, at the present conditions, housing scarcity exacerbates affordability problems. In general, there are a variety of possible policy instruments that could be applied to improve affordability on the existing stock and without new housing production (e.g., rent control) that are, however, beyond the scope of this paper. Here it is useful to stress that land consumption should be avoided and, when not possible, it should be primarily, if not exclusively, to promote the social function of housing and not for market reasons. In recent years, low interest rates have spurred a construction boom and international and national private investments in large-scale residential buildings. In the past few years, privately produced dwellings have outnumbered the affordable ones as a result of high land prices. Often, they are not used for housing but for investment (i.e., short term) with controversial effects, since they do not respond to the actual housing need which remains latent and unsolved. Therefore, control on land is crucial in avoiding a "waste" in housing production and assuring that the produced housing is targeted at those most in need.

In this sense, we could underline a very different approach in Milan and Vienna. In Milan, land is treated mainly as a commodified and exchangeable good and also publicly owned land (e.g., from the municipality or the railway company) is frequently sold at auction. In Vienna, there are strong instruments of control on land that is mainly performed through land procurements and land banking (Peverini, 2021). Banked land is managed and leased to limited-profit housing providers in a competitive system by the Vienna Housing Fund (Wohnfonds Wien) called Bauträgerwettbewerb (developer competition): In this way, the produced dwellings are permanently rent-controlled and address the needs of low- and middle-income tenants, with very low commodification (ibidem). The groundwork for this highly successful model was laid more than 100 years ago and has been safeguarded by the City of Vienna ever since by not selling public housing estates and residential buildings to private investors and keeping a land reserve for future housing development. The majority of dwellings provided by these profit-driven investors lack the level of quality of the affordable housing projects realized through the competition system which had to pass a multidisciplinary jury of the housing commission called the Grundstücksbeirat (land commission).

\subsubsection{Scarcity of Materials and High Construction Costs}

As mentioned, building materials represent another crucial aspect of housing production and transformation that influences both affordability and environmental outcomes. Norms play a role since increasing standards require more expensive materials and processes, but the supply chain also influences the final costs. In Vienna, since 2015, the resulting construction boom has caused a severe cost increase for all. Limited-profit housing developers were struggling to receive an offer from construction companies due to high demand from the private sector willing to pay higher prices. The public subsidy for affordable housing is contractually bound to a maximum rent of $€ 7.50 / \mathrm{m}^{2}$, compared to double or triple prices achievable on the private market. As a result, the non-profit housing developers have not much room for negotiations with the construction companies. In Milan, this is coupled with a very heated land market and the speculative action of private and often also public actors, resulting in higher final costs. The Covid-19 
crisis has intensified this trend and worsened the cost increases. Firstly, hesitancy in the ordering of necessary material on the side of the construction companies diverted the resources elsewhere, e.g., Austrian timber being sold to the US and Canada at higher prices, resulting in up to an eight-fold increase in timber prices. Secondly, lockdowns and illness clusters have slowed down production and, most importantly, shipping from overseas. Unfortunately, in the last decades, even locally available materials such as granite were imported from remote countries, mostly China, for cost-saving reasons. Sustainability arguments against such environmentally unfriendly practices went unheard. Now, transport costs have been rising and long-distance imports have become unreliable when sudden Covid-19-related closures of a harbor delay the transport of goods. Moreover, there are signs of a trade off in treating housing production as an economic activity to drive the economic recovery. In Italy, the recently introduced stimulus measures for the economy regarding incentives for retrofitting (the so-called "superbonus") have exacerbated the scarcity of building materials and increased costs. For those reasons, it is of primary importance not only to avoid land consumption but also to find ways to overcome material scarcity, and $\mathrm{CE}$ is a potentially revolutionary tool. The EU Green Deal has the potential to revert the trend towards an environmentally conscientious practice using locally fair-produced materials and reuse and recycle.

\section{A Critical Reflection on Current Renovation Models}

\subsection{Paradoxes of Renovation}

Current renovation models to improve the situation of the old housing stock (which represents the majority) mainly target energy performances. A typical example is the addition of facade insulation to the existing building. These solutions are often able to reduce the energy consumption of the building and the energy bills for the inhabitants and to improve thermal comfort. However, acting only on the surface usually means not changing the layout of the flats and adapting the dwellings to contemporary housing needs and practices. Some interesting (and contrasting) examples in this sense can be illustrated. The first two are related to the renovation of the public mass housing stock produced mainly during the 1960s and 1970s. The first is the partial renovation of the public housing neighborhood of Gratosoglio, in the south of Milan, mainly composed of towers and slabs built during the 1960s and 1970s. In the 2010s, a renovation process was carried out on around half of the buildings (Fig. 2). To enable the inhabitants to remain at home, the renovation focused solely on the surface of the buildings, with the application of insulation to the existing facades (Fig. 3) ${ }^{9}$. Except for changing the aesthetics of the buildings and their energy performances, this did not involve any improvement in the layout and in the facilities. In a similar situation, in France, the award-winning architects Lacaton and Vassal, Frédéric Druot and Christophe Hutin have experimented with a different model of renovation. Still minimizing the annoyance to the inhabitants, it entails a more significant transformation of the living space through the creation of a new thick layer (Fig. 4) ${ }^{10}$. This new layer allows for generous extensions to the flats, with winter gardens, balconies or additional rooms, and provides a new and different quality to the housing after the renovation (Fig. 5). These two examples have been chosen, since they extended the useful life of buildings produced over fifty years ago that were high energy-consumers, but they were not demolished. The precarious conditions of tenants during the construction work has made renovation more attractive than demolition. In any case, they illustrate how renovation can be carried out in different ways: simply improving energy performances or also giving new quality to the space.

A different approach, more sensitive to the specificities of the building, is evidenced by the renovation of an abandoned 19th century structure in a central neighborhood of Vienna carried out by architects 
Gaupenraub+/- for the religious association Vinzensgemeinschaft. In this case as well, the old building could have been demolished but both the client and the architects opted for renovating the existing one, trying to take advantage of its specific features. Although the roof was demolished to add another floor and a roof garden, the rest of the building was preserved and refurbished. In particular, an important base of volunteers made it possible to reuse the parts of the buildings that would have otherwise been removed, such as the wooden floor of the attic, which was reinstalled on the ground floor, or an iron pergola for the courtyard (Fig. 6). Even used fruit crates were collected to decorate the restaurant, and workshop rooms are dedicated to handwork involving the reuse and upcycling of materials (Fig. 7).

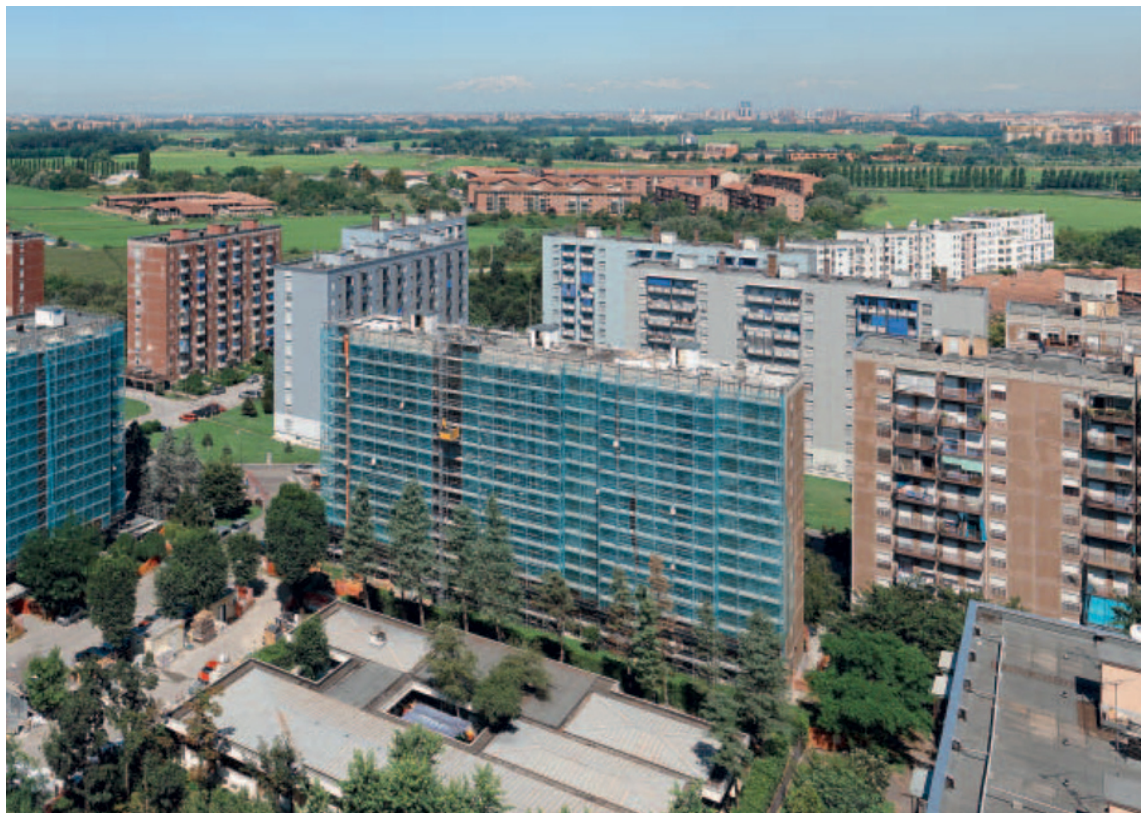

Figure 2. The buildings of Gratosoglio during the renovation. Source: Arketipo

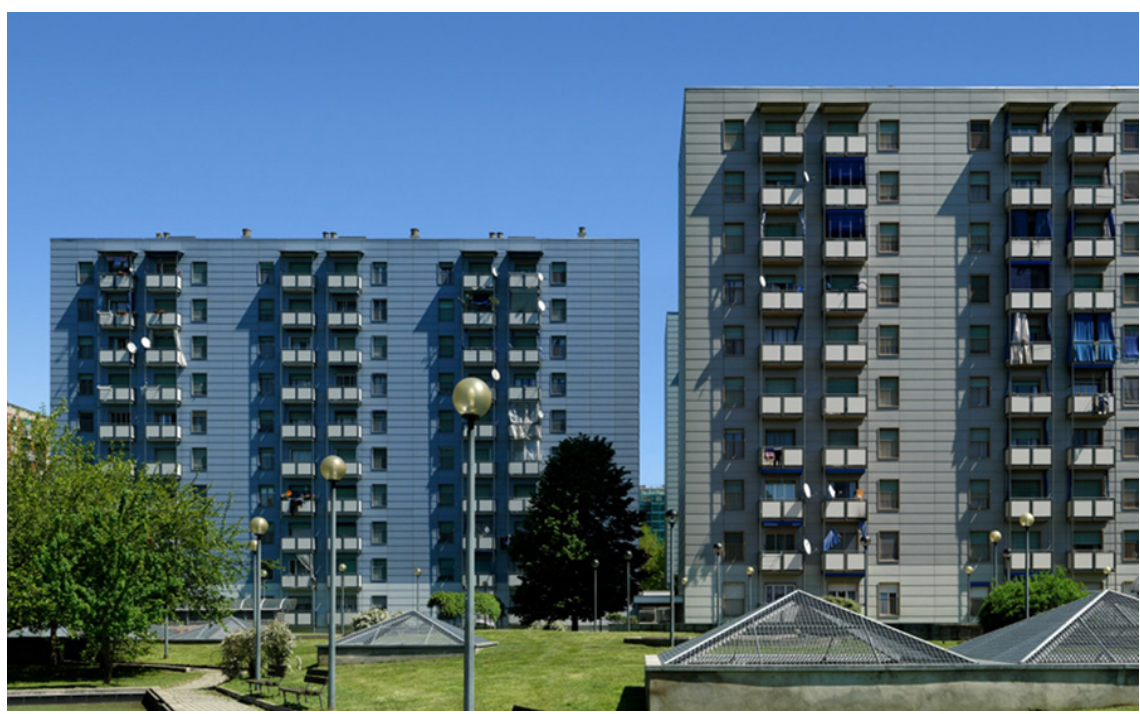

Figure 3. The buildings of Gratosoglio after the renovation. Source: Arketipo 


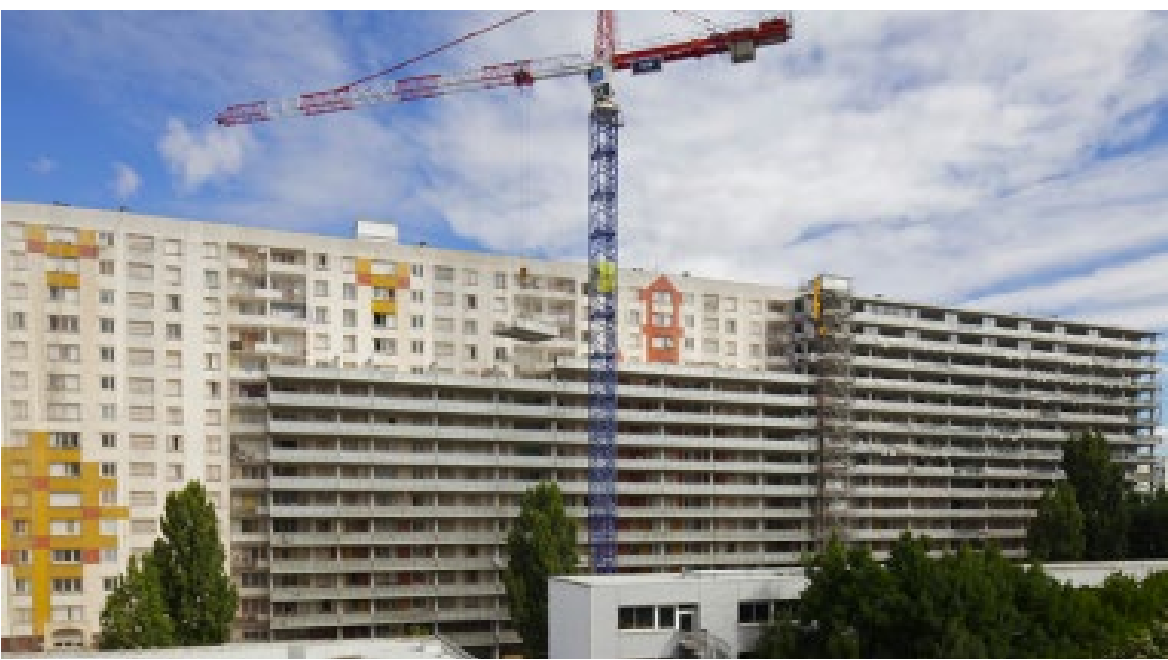

Figure 4. Transformation of 530 dwellings during construction work. Copyright: Philippe Rualt

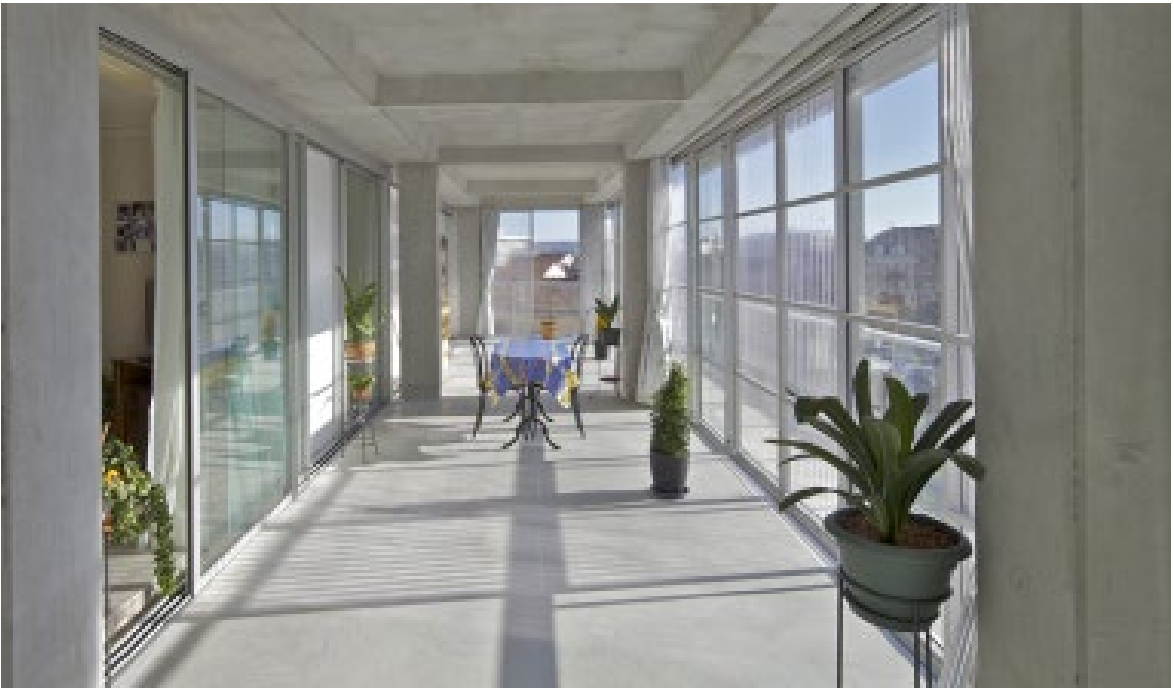

Figure 5. The newly created balcony/winter garden. Copyright: Philippe Rualt

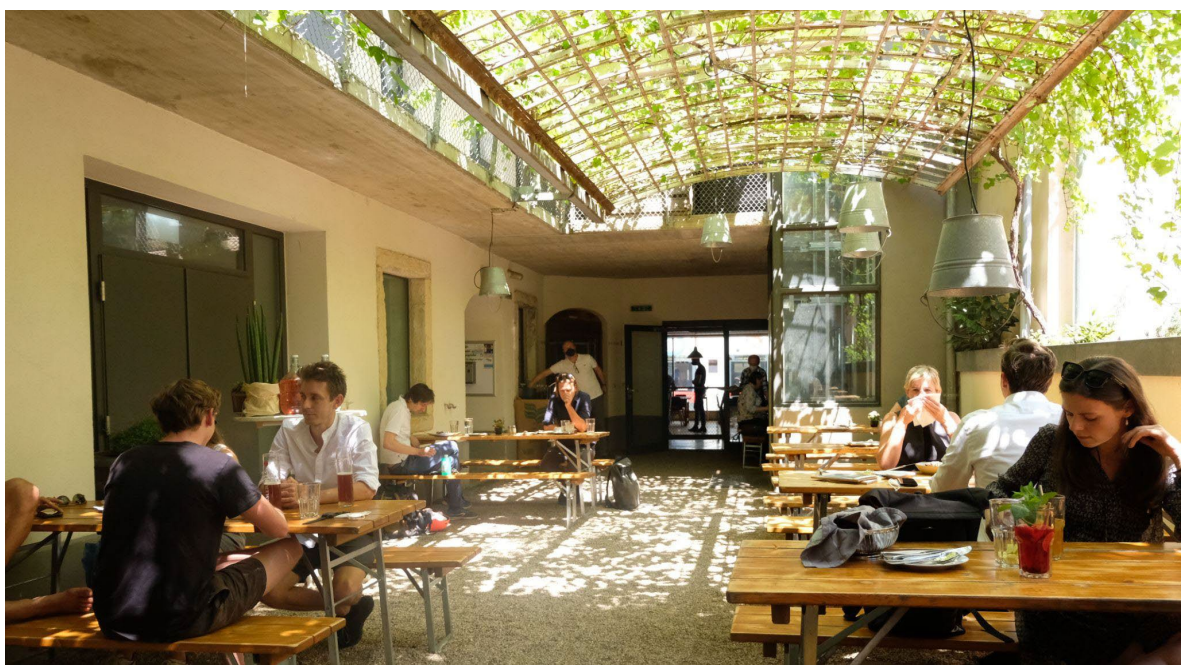

Figure 6. The courtyard with the reused iron pergola. Source: Marco Peverini 


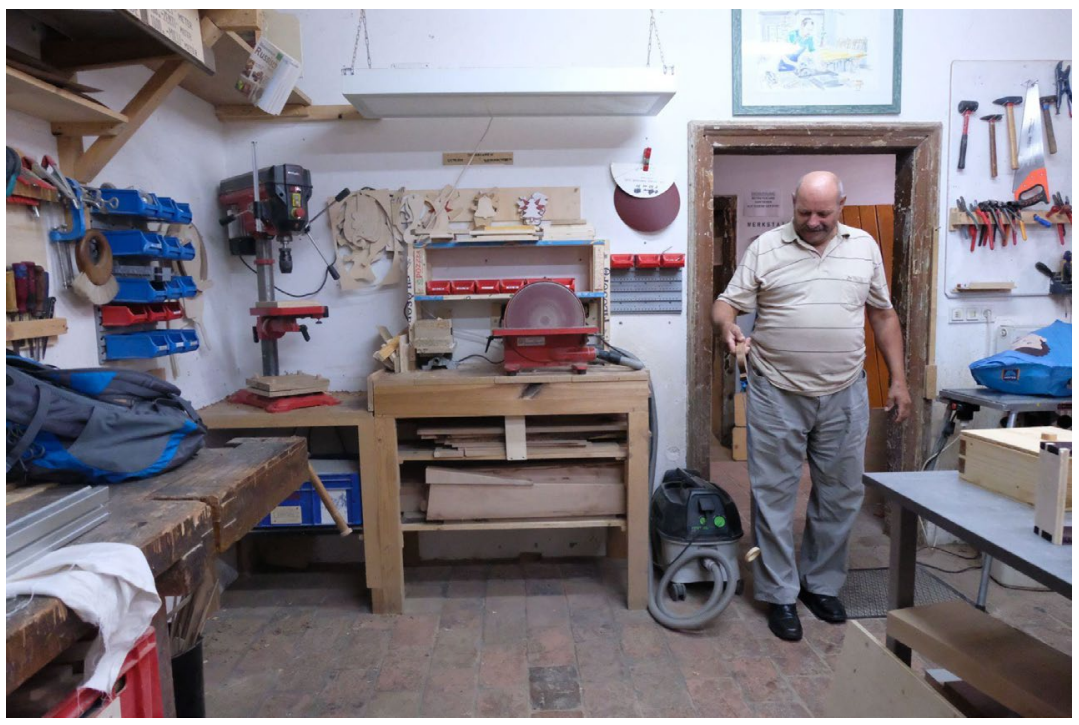

Figure 7. The workshop where materials are upcycled. Source: Marco Peverini

\subsection{Blocksanierung - Vienna's Gentle Urban Renewal System Supported by the Wohnfonds}

The system was founded over 30 years ago to upgrade large housing blocks in the densely built districts of Vienna. In the beginning phase, there were considerable numbers of buildings with inadequate sanitary facilities, low energy performance and a lack of private or communal open spaces. In coordination with districts and municipal authorities, Wohnfonds Wien develops sustainable concepts for the upgrading of entire blocks of houses.

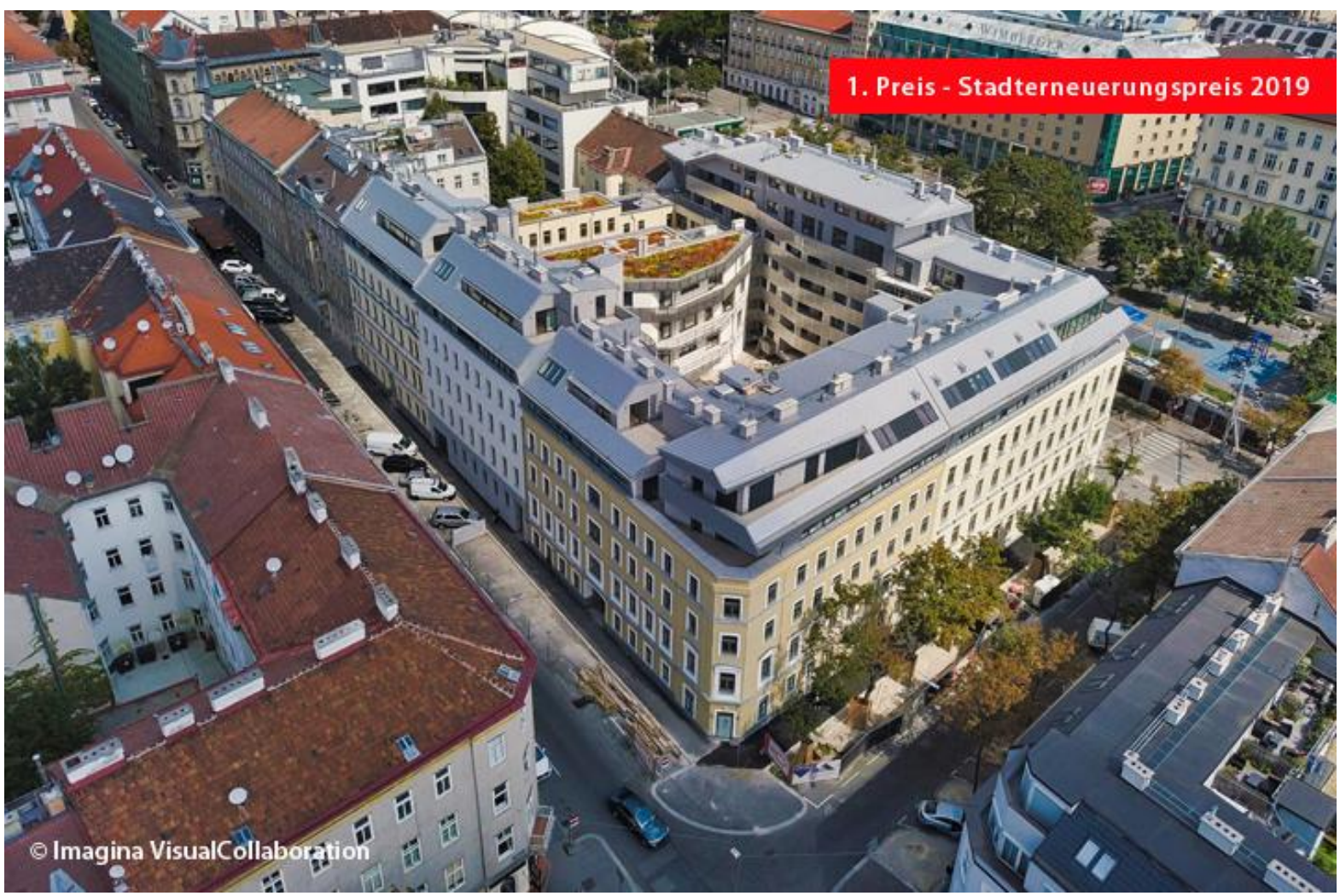

Figure 8. Refurbishment of a Gründerzeit housing block, Vienna Goldschlagstr., with additions and greening, Source: PGood 
The Sanfte Stadterneuerung (gentle urban renewal) entails different schemes:

-THEWOSAN: thermal-energetic housing refurbishment

-Basic refurbishment: comprehensive modernization of inhabited houses

-Total refurbishment: thorough renovation of uninhabited houses

-Individual improvement measures: e.g., elevators, measures to enable accessibility, fitting of sound insulation windows, improvement of housing comfort

-Block renewal: sustainable development in underprivileged residential areas by eliminating urban deficiencies while providing infrastructure, etc., in accordance with needs of neighbourhood residents.

The policy is area-based (Fig. 9), and since 1984 has involved 7,463 residential buildings with 345,000 dwellings, for approx. $€ 8.15$ billion total rehabilitation costs and $€ 5.34$ billion in subsidies from the City of Vienna, reducing the heat demand of 1,157 GWh/year and greenhouse gas emissions of approx. 371,400 tons $\mathrm{CO}_{2} /$ year $^{11}$.

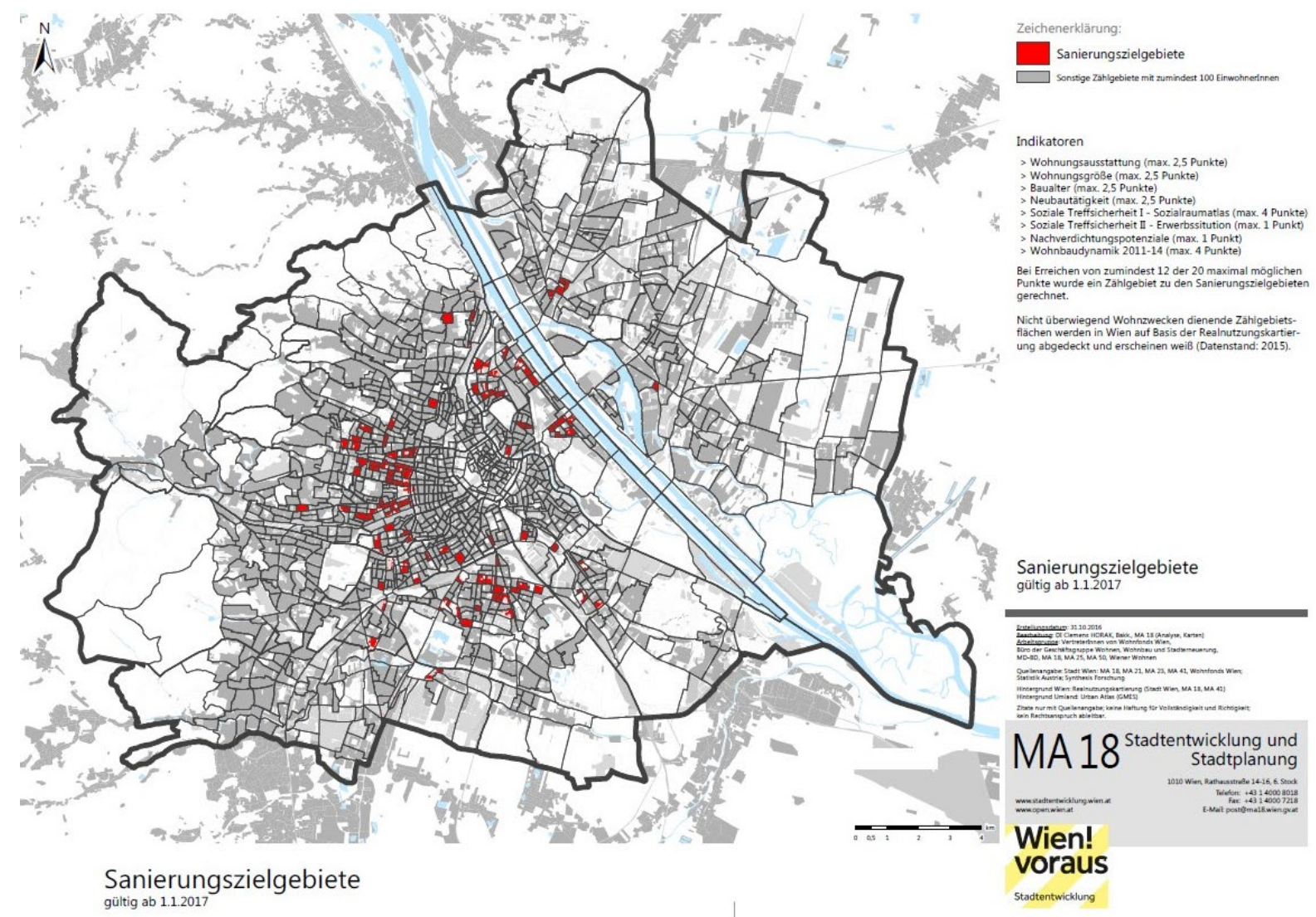

Figure 9. Urban renewal areas for the 2017 renewal policy. Source: MA18, Wohnfonds_Wien.

Today, the goal of Vienna's urban renewal is to make the quality of life in the densely built-up Gründerzeit neighborhoods even more attractive and promote contemporary living in old buildings. Quality and sustainability have top priority. The main focus is on improving the thermal and energy properties of buildings. The goal has always been high-quality housing that is affordable. Thanks to this system, many historic buildings without monument protection have been safeguarded, renovated and upgraded. Specific to Vienna is the focus on affordability which has influenced housing policies for one hundred years. 
Funding is only granted if the rents are kept affordable, a rise is allowed only for a maximum period of fifteen years to pay back renovation costs, then has to return to the original amount.

The process: Individual building owners can apply for funding if they fulfill the criteria, i.e., work with an architect and technical engineers, develop a sustainable concept of high quality that has to be approved by the Grundstücksbeirat, the Vienna Housing Commission, before funding is granted. Often, this advisory board makes recommendations for improvements that have to be fulfilled. A wien neu project (small block redevelopment) enables the implementation of urban structural improvements on a single property also outside an entire block redevelopment area.

Participation of stakeholders and residents: Within the framework of gentle urban renewal, the quality of living and the living environment are upgraded with the involvement of residents. The process: Wohnfonds Wien guides building owners and managers through the process of subsidized refurbishment from the first planning steps, including the subsidy application, to the completed project. The correct use of subsidies is monitored, and all calculations have to be made transparent.

\section{Toward a Circular Economy Applied to Refurbishment, Some Good Examples}

\subsection{The Principles of a Circular Economy}

Circular economy means following the cradle-to-cradle principle by securing the eternal use and reuse of a product and its components and avoiding waste. It is much more than just recycling and closing the material cycles. It implies a paradigm shift towards new strategies that close the cycle by integrating the principles of circular economy into the design from the beginning. Resource efficiency counts in the production phase, in the use phase and at the end of the life-cycle by saving the residual value (Fig. 10).

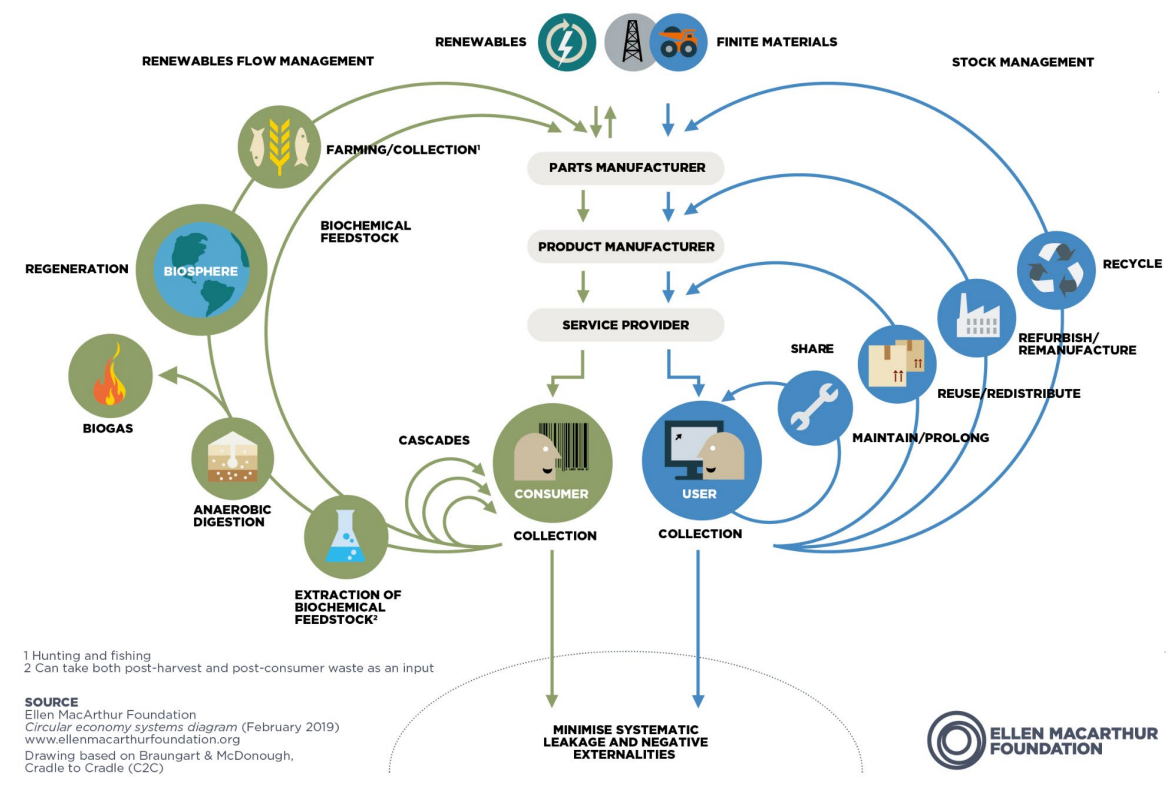

Figure 10. Circular economy systems diagram as a butterfly infographic. Source: Ellen Macarthur Foundation.

Following the principles of circular economy in production and use means applying a new business model. Instead of producing and vending with a maximum profit without following its life-span, the product itself is seen as a resource (Fig. 11). The consumer and the client are no longer just users, but also the material 
depot. Positive examples include lease models, where at the end of the use phase the product is either repaired, refurbished or taken back and its components reused for an equal purpose without downcycling. This innovative way of doing business has been implemented by companies as varied as Philips with light as a service, USM Haller for their office furniture or a jeans producer in Holland. The positive result is a more intensive and long-term business relationship between producer and consumer. The market response, e.g., in Holland, surprised many furniture producers in 2017 when it went out to bid for $€ 200$ million of office furniture in a circular economy model instead of a purchase model.

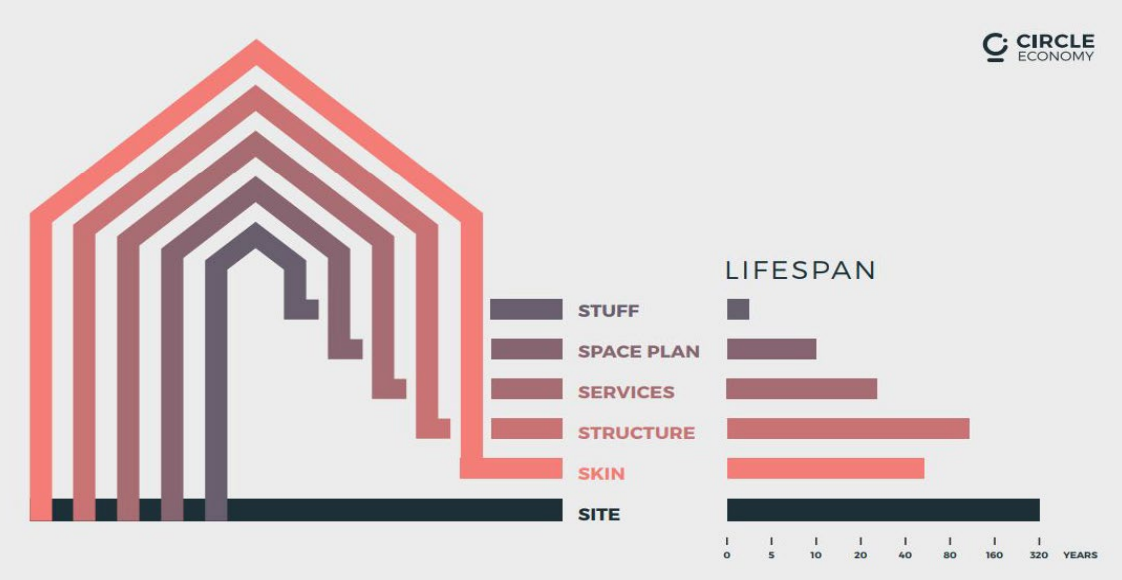

Figure 11. The duration of use of different components in a building, shown in building layers, adapted from Steward Brand, 1995. Source: Circle Economy.

\subsection{Application of Circular Economy Principles to Buildings and Renovation}

In Austria, the entire demand for new housing and work places could be integrated into the existing unused building stock. Although some of the unused buildings are situated in unattractive locations or in industrial zones, a creative reuse process could reintegrate many of them into the real estate market. The most ecological measure therefore was to always prioritize reuse rather than demolish and rebuild.

Unfortunately, this is not the way the construction industry works. Traditionally, institutions as well as private clients follow fixed budgets for a project based on new construction and sale or lease. In this model, the calculations of their business model do not follow life-cycle costs. In a new business model, the costs have to be calculated for the entire life-span of a building. Some public clients already demand this, e.g., BIG Austria, the public building and real estate holding of the Austrian Federal Government, now requires life-cycle cost calculation in competitions from the bidders. The 10 Rs of circular economy describe perfectly how to deal with construction and their most effective implementation is the reuse of existing buildings (Table 1 ).

\begin{tabular}{|l|l|l|l|}
\hline 1. Refuse & $\begin{array}{l}\text { E.g. asbestos, oil-fired } \\
\text { heating systems }\end{array}$ & 6. Refurbish & Renew and upgrade \\
\hline 2. Rethink & & 7. Remanufacture & Refabricate \\
\hline 3. Reduce & & 8. Repurpose & Find new uses \\
\hline 4. Reuse & & 9. Recycle & \\
\hline 5. Repair & & 10. Recover & \\
\hline
\end{tabular}

Table 1. The ten "Rs" of CE. 
The site of a building is used only once in its life-span, an average of 320 years. Depending on the construction type, the structure may change after approximately 80 years, the building skin after an average duration of 40 years. Many historic buildings demonstrate how structures and facades built of stones can last for centuries. The shortest life span is in the furniture, named "stuff" in the diagram and the partition walls depending on the space plan (Fig. 12).

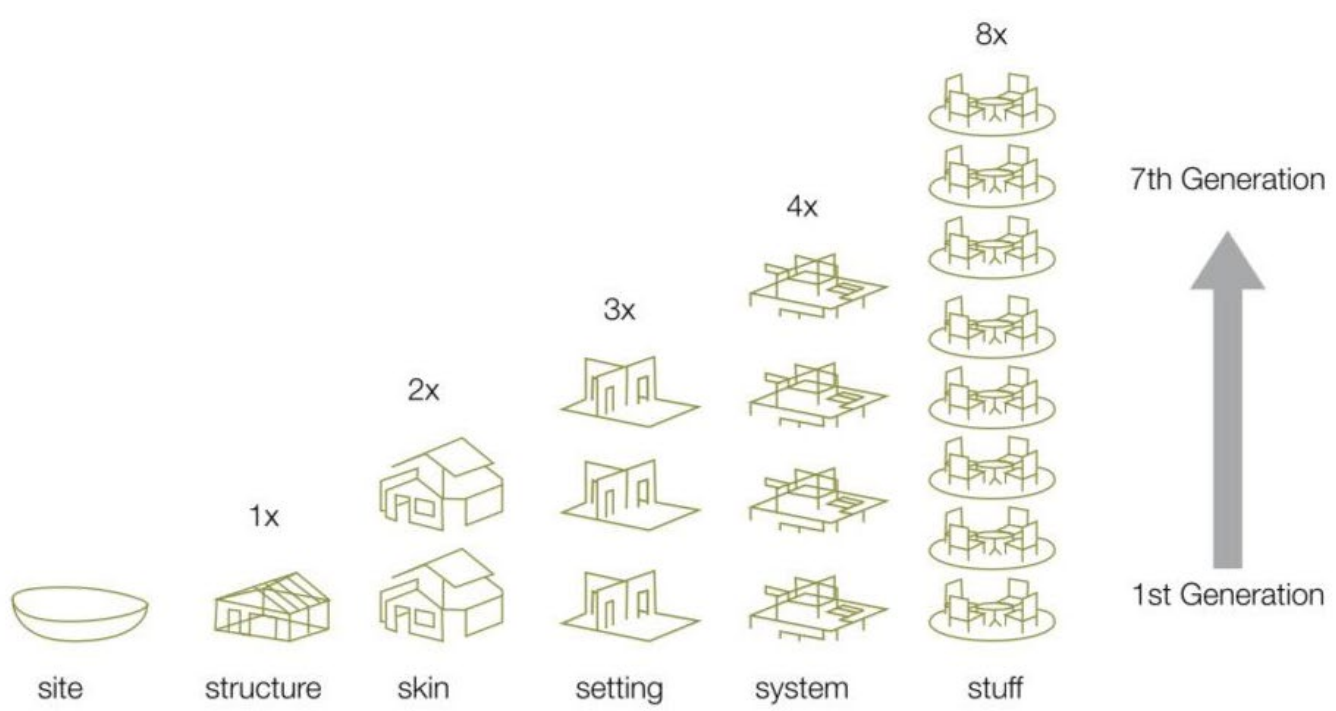

Figure 12. Number of times material and system cycle through a building in a single lifetime. Source: Mcdonough.

Therefore, the biggest impact can be achieved by addressing these most dynamic components and transforming them towards the circular economy. This can be achieved by designing for flexibility and planning for potential future changes by the users. The innovative models of leasing furniture instead of buying it reduce waste entirely. While this offer exists already for office furniture, residential furniture for housing lags behind. This is currently changing as even Ikea announced at the opening of its ecological and landscaped new city store in Vienna to take back furniture and pay $30-50 \%$ of its purchase price, depending on the condition. Circular economy means following the cradle-to-cradle principle in production and use, the adaptation of the users' behaviour and the transformation from ownership to sharing.

\section{Conclusions and Outlook}

The paper has illustrated some of the problems and trends that simultaneously challenge affordability and environmental sustainability in housing. The first important conclusion is the necessity to shift away from new construction and soil consumption to refurbishment of the already oversized built stock. However, renovation challenges traditional modes of housing production and transformation, and can be performed in different ways. Illustrating and discussing some concrete examples of refurbishment, in Section 2, shows how renovation is not effective if it only tackles energy performances, as in the Italian case; that renovation could also involve the adaptation of the residential space to the contemporary needs and comfort requirement, as in the French case; how it can include the careful reuse of existing material and the possibility to exploit other used materials, as in the Viennese case. Finally, the policy for "gentle urban renewal" is interesting because it finances refurbishment that simultaneously targets environmental sustainability, the comfort of the inhabitants (i.e., the elimination of substandard conditions), neighborhood services and affordability (by imposing rent control and avoiding "renoviction"). All these examples head towards the principles, now officially endorsed by the new EU regulations, of circular economy that were illustrated in Section 3: Integrating the ten "Rs" of CE in the refurbishment of the 
existing built stock is a challenging task for designers, researchers and policy-makers that cannot be further postponed.

\section{References}

Agenzia delle Entrate (2019), Lo stock immobiliare in Italia: analisi degli utilizzi. link.

Istat (2020), Popolazione e famiglie. link.

Knoll K., Schularick M., and Steger T. (2017), "No price like home: Global house prices, 1870-2012," American Economic Review, 107(2): 331-353.

Peverini M. (2021), "Grounding urban governance on housing affordability: a conceptual framework for policy analysis. Insights from Vienna," Partecipazione e Conflitto, 14(2): 848-869.

Wetzstein S. (2017), "The global urban housing affordability crisis," Urban Studies, 54(14): 3159-3177.

\section{Notes}

${ }^{1}$ Source: Statistik Austria.

${ }^{2}$ www.ec.europa.eu, accessed 09/03/21.

${ }^{3}$ www.eur-lex.europa.eu, accessed 09/03/21.

${ }^{4}$ www.europa.eu, New European Bauhaus, accessed 09/03/21.

${ }^{5}$ www.eur-lex.europa.eu. directive: energy performance of buildings 2010/31/EU, version 26/02/2021.

${ }^{6}$ www.oib.or.at, OIB-Richtlinie 6, Langfristige Renovierungsstrategie.

7 https://eur-lex.europa.eu/resource.html

${ }^{8}$ https://ec.europa.eu/info/business-economy-euro/banking-and-finance/sustainable-finance/eu-taxonomy-sustainable-activities en

${ }^{9}$ https://www.arketipomagazine.it/swisspearl-per-il-quartiere-gratosoglio-di-milano/, accessed 13/09/2021

${ }^{10} \mathrm{https}$ ://www.pritzkerprize.com/laureates/anne-lacaton-and-jean-philippe-vassal\#, accessed 14/09/2021

11 Data presented by Susanne Bauer, of Wiener Wohnen, in 2019. Source: https://www.federcasa.it/wpcontent/uploads/2019/07/20190528_Vienna_Gentle-Urban-Renewal.pdf 